\title{
PENGARUH PERENCANAAN DAN PENGEMBANGAN SUMBER DAYA MANUSIA TERHADAP KINERJA KARYAWAN PT PERMATA BAHARI MALINDONESIA
}

\author{
Rizky Trisna Firman Haqiqi \\ Department of Management FEB UMM \\ E-mail: rizkyfirmanhakiky@gmail.com
}

\begin{abstract}
The purpose of this study was to describe the planning, development, and employee performance, and analyze the influence of planning and human resource development of the employee performance of PT Permata Bahari Malindonesia. analyzer used to describe human resource planning, human resource development, and employee performance is a range of scales. To analyze the influence of human resource planning and human resource development of employee performance is multiple linear regression analysis and the hypotheses test using f test and t test.The results of the analysis for the range scale for human resource planning including the very good category with the average score of 165, so it also the human resource development categories including the very good with the average score of 165 and employee performance including in the very high with the average score of 163. While the results show human resource planning has significant influence to employee performance and has significant influence to employee performance.
\end{abstract}

Keywords: Human Resource Planning, Human Resource Development, Employee Performance

\section{PENDAHULUAN}

Suatu kesenjangan antara penawaran dengan permintaan sumber daya manusia dalam sebuah perusahaan atau organisasi menjadi suatu hal yang perlu diperhatiakan dalam pengambilan keputusan manajemen tingkat atas. Dalam sebuah perusahaan atau organisasi, segala aktifitas akan saling terkait dan berkesinambungan antara atasan dengan bawahan. Ketidakpastianketidakpastian di masa yang akan datang menjadi sebuah rangkaian roda yang akan terus berputar yang bisa saja menggilas atau bahkan membawa perusahaan atau organisasi ke arah yang lebih baik.
Dari rangkaian-rangkaian ketidakpastian tersebut, diperlukan suatu pemikiran atau upaya untuk menurunkan berbagai ketidakpastian tersebut. Salah satunya dengan melakukan perencanaan strategis untuk merumuskan masalah kesenjangan antara penawaran dengan permintaan sumber daya manusia dalam sebuah perusahaan atau organisasi. Dalam hal ini perencanaan sumber daya manusia digunakan sebagai cara untuk mengantisipasi ketidakpastian pada masa yang akan datang. Mengantisipasi kebutuhan sumber daya manusia di masa depan sertaperencanaan pemenuhan 
kebutuhan sumber daya manusia tersebut merupakan bagiandalam perencanaan sumber daya manusia yang meliputi pencapaian tujuan danimplementasi program-program. Dalam perkembangannya, perencanaan sumber daya manusia juga meliputi pengumpulan data yang dapat digunakanuntuk mengevaluasi keefektifan programprogram yang sedang berjalan danmemberikan informasi kepada perencanaan bagi pemenuhan kebutuhan untuk revisiperamalan dan program pada saat diperlukan (Bakar, 2011:3).

Perencanaan sumber daya manusia merupakan satu paket kegiatan sumber daya manusia yang terdiri dari analisis pekerjaan, rekrutmen dan seleksi yang harus mampu menghindari kekeliruan dalam bentuk mempekerjakan pekerja yang seharusnya ditolak atau sebaliknya mempekerjakan sumber daya manusia yang seharusnya diterima. Perencanaan sumber daya manusia harus mampu memberikan pedoman mengenai persyaratan dalam pengadaan dan pengembangan sumber daya manusia yang seharusnya dipekerjakan di lingkungan sebuah organisasi atau perusahaan (Nawawi, 2005:104).

Pada dasarnya kualitas kinerja sumber daya manusia dalam suatu perusahaan perlu diperhatikan demi kelangsungan perusahaan. Dalam upaya meningkatkan dan menjaga kualitas sumber daya manusia yang tersedia dalam perusahaan maka diperlukan langkah-langkah yang kemungkinan tingkah laku dapat diramalkan dengan analisis informasi tentang individu atau sumber daya manusia tersebut.

Pengembangan sumber daya manusia dipandang sebagai peningkatan kualitas sumber daya manusia melalui program-program pelatihan dan maka kinerja karyawan juga dinyatakan baik dan sukses (Riva'i, 2005:309). Kinerja yaitu hasil kerja yang dapat dicapai oleh seseorang dalam suatu organisasi baik secara kuantitatif maupun kualitatif, sesuai kewenangan dan tugas tanggung jawab masingmasing, dalam upaya mencapai tujuan organisasi bersangkutan secara legal, tidak melanggar hokum dan sesuai dengan moral maupun etika(Moehariono, 2010:61).

Ditengah persaingan perusahaan yang semakin ketat serta ditambah keadaan alam dan ekosistem laut yang semakin rusak, PT Permata Bahari Malindonesia merupakan perusahaan domestik yang masih mampu bertahan dalam menghasilkan produk setengah jadi yang berupa ikan kaleng. Perusahaan ini terletak di Kecamatan Muncar Kabupaten Banyuwangi yang merupakan salah satu penghasil ikan terbesar di Indonesia. Pada pertengahan tahun 2010 hingga tahun 2013 produksi ikan di laut Muncar mengalami penurunan secara drastis sehingga hal tersebut mengakibatkan perusahaan harus megurangi produksinya bahkan tidak sedikit karyawan yang berhenti bekerja.

Hal ini mengakibatkan banyak karyawan menganggur karena perusahaan telah mengurangi produksinya. Beberapa karyawan memilih untuk keluar dan cari pekerjaan lain. Terlebih beberapa 
karyawan senior ikut keluar untuk mencari pekerjaan di tempat lain.

Pada pertengahan tahun 2013 produksi ikan di laut Muncar mulai membaik kembali sehingga perusahaan semestinya mampu memproduksi ikan kaleng kembali. Dengan melimpahnya bahan baku semestinya perusahaan dapat memproduksi lebih banyak dari tahun sebelumnya. Namun hal ini tidak mampu dilakukan karena terkendala dari beberapa karyawan terutama karyawan baru kurang mencukupi baik dari kemampuan maupun pengalaman. Dengan demikian pada tahun 2014 kinerja sumber daya manusia yang ada pada perusahaan dinilai kurang mampu memenuhi kebutuhan untuk produksi di perusahaan tersebut.

Hal ini ditunjukkan dengan masih banyaknya kegagalan karyawan dalam melaksanakan tugas yang diberikan oleh perusahaan. Dalam periode 2014 jumlah kegagalan dalam bekerja dinilai masih cukup banyak terutama pada karyawan produksi pada bagian pemotong ikan. Hal ini dapat dilihat pada tabel produksi pemakaian ikan sebagai

berikut:

Tabel 1. Data produksi pemakaian ikan PT Permata Bahari Malindonesia tahun 2014

\begin{tabular}{|c|c|c|c|c|c|c|}
\hline \multirow[b]{2}{*}{ Bulan } & \multicolumn{2}{|c|}{ Pemakaian Ikan } & \multicolumn{2}{|c|}{ Ikan yang rusak (kg) } & \multicolumn{2}{|c|}{ Persentase kerusakan } \\
\hline & $\begin{array}{c}\text { Sardines } \\
425 \\
\text { (ekspor) }\end{array}$ & $\begin{array}{c}\text { Sardines } \\
155 \text { (lokal) }\end{array}$ & $\begin{array}{c}\text { Sardines } \\
425 \\
\text { (ekspor) }\end{array}$ & $\begin{array}{c}\text { Sardines } \\
155 \text { (lokal) }\end{array}$ & $\begin{array}{c}\text { Sardines } \\
425 \\
\text { (ekspor) }\end{array}$ & $\begin{array}{c}\text { Sardines } \\
155 \\
\text { (lokal) }\end{array}$ \\
\hline Januari & 60980 & 1985 & 329 & 54 & $0.5 \%$ & $2.7 \%$ \\
\hline Februari & 58716 & 1786 & 364 & 68 & $0.6 \%$ & $3.8 \%$ \\
\hline Maret & 61750 & 1678 & 335 & 57 & $0.5 \%$ & $3.4 \%$ \\
\hline April & 57320 & 1782 & 320 & 44 & $0.6 \%$ & $2.5 \%$ \\
\hline Mei & 58650 & 1865 & 406 & 67 & $0.7 \%$ & $3.6 \%$ \\
\hline Juni & 56935 & 1790 & 392 & 70 & $0.7 \%$ & $3.9 \%$ \\
\hline Juli & 57146 & 1765 & 445 & 69 & $0.8 \%$ & $3.9 \%$ \\
\hline Agustus & 59745 & 1862 & 452 & 65 & $0.8 \%$ & $3.5 \%$ \\
\hline September & 58145 & 1785 & 487 & 72 & $0.8 \%$ & $4.0 \%$ \\
\hline Oktober & 59760 & 1865 & 503 & 81 & $0.8 \%$ & $4.3 \%$ \\
\hline November & 58756 & 1852 & 498 & 84 & $0.8 \%$ & $4.5 \%$ \\
\hline Desember & 57416 & 1842 & 515 & 86 & $0.9 \%$ & $4.7 \%$ \\
\hline
\end{tabular}

Dari data pada Tabel 1 menjelaskan bahwa masih banyak kegagalan-kegagalan dalam melaksanakan tugas yang dilakukan oleh karyawan. Perusahaan telah menentukan standar kerusakan minimal $0,5 \%$ dalam satu bulan untuk jenis sardines 425 sedangkan untuk jenis sardines 155 kerusakan minimal 2,5\% dalam satu bulan dengan target produksi 50000-70000 $\mathrm{kg} /$ bulan untuk jenis sardines 425 dan 1500-2000 kg/bulan untuk jenis sardines 155 .

Perusahaan membutuhkan karyawan yang mempunyai kinerja yang baik yaitu mampu menghasilkan produk dengan kualitas dan mutu yang sesuai dengan standar perusahaan. Karyawan produksi pada bagian pemotong ikan sering terjadi kesalahan yaitu pemotong kepala ikan sering kali tidak sesuai dengan 
standar yang ditetapkan perusahaan. Pemotongan yang sesuai standar perusahaan harus tepat diatas badan ikan dan organ dalam ikan harus ikut terbuang dengan bersih selain itu ukuran pemotongan harus sesuai dengan jenis produk untuk ekspor atau pun lokal.

Kegagalan karyawan dalam melaksanakan tugas ini menyebabkan perusahaan kurang efektif dan efisien dalam mencapai tujuannya. Standar pekerjaan diperlukan dalam menentukan target yang ingin dicapai oleh karyawan. Keahlian atau kemampuan karyawan akan mempengaruhi kinerjanya, oleh karena itu pelatihan dan pendidikan diperlukan untuk menciptakan tenaga kerja yang berkualitas. Selain itu peningkatan kewenangan atau tanggung jawab akan menjadikan karyawan lebih mandiri dan berkarakter dalam melaksanakan tugasnya. Tidak adanya hal-hal tersebut yang akan menyebabkan kegagalan dalam bekerja.

Berdasarkan fenomena tersebut peneliti membuat rumusan masalah sebagai berikut, Bagaimana perencanaan, pengembangan sumber daya manusia, dan kinerja karyawan pada PT Permata Bahari Malindonesia?, Apakah perencanaan sumber daya manusia berpengaruh signifikan terhadap kinerja karyawan?, Apakah pengembangan sumber daya manusia berpengaruh signifikan terhadap kinerja karyawan?.

\section{TINJAUAN PUSTAKA}

Menurut Hasibuan (2009:250), perencanaan sumber daya manusia adalah merencanakan tenaga kerja agar sesuai dengan kebutuhan perusahaan serta efektif dan efisien dalam membantu terwujudnya tujuan. Ciri-ciri perusahan tersebut dilihat dari informasi tentang: Job Analysis, memberikan informasi tentang aktivitas pekerjaan, standar pekerjaan, konteks pekerjaan, persyaratan personalia, perilaku manusia, dan alat-alat yang digunakan. Job description, memberikan informasi tentang tugastugas dan tanggung jawab seorang pejabat dalam suatu jabatan. Job specification, memberikan informasi tentang kualifikasi-kualifikasi SDM yang akan menjabat suatu jabatan.

Job evaluation, memberikan informasi mengenai berat ringannya pekerjaan, resiko pekerjaan, dan gaji jabatan. Job enrichment, memberikan informasi untuk memperkaya pekerjaan pada suatu jabatan tertentu yang sifatnya vertical. Job enlargement, dapat memberikan informasi untuk memperkaya jenis pekerjaan yang sifatnya horizontal. Work simplification, memberikan informasi untuk spesialisasi pekerjaan.

Pengembangan sumberdaya
manusia (human development) adalah proses untuk meningkatkan kemampuan sumber daya manusia dalam membantu tercapainya tujuan organisasi. Kemampuan sumberdaya manusia dalam perusahaan dapat ditingkatkan melalui program-program pelatihan dan pendidikan. Pelatihan karyawan akan dilakukan bagi karyawan yang dinilai kurang terampil dalam mengerjakan pekerjaanya (Bangun, 2012:200).

Menurut Riva'i (2004:240) dalam melaksanakan program 
pendidikan dan pelatihan ada beberapa syarat yang harus dipenuhi yaitu identifikasi kebutuhan, instruktur (pelatih), peserta, materi (bahan), metode, tujuan pelatihan dan lingkungan yang menunjang.

Menurut Bangun (2012:231) kinerja adalah hasil pekerjaan yang dicapai seseorang berdasarkan persyaratan-persyaratan pekerjaan.
Untuk menentukan kinerja karyawan baik atau tidak tergantung pada hasil perbandingannya dengan standar pekerjaannya. Standar kinerja adalah tingkat yang diharapkan suatu pekerjaan tertentu untuk dapat diselesaikan dan merupakan pembanding atas tujuan atau target yang ingin untuk dicapai. Kerangka penelitian ini adalah sebagai berikut.

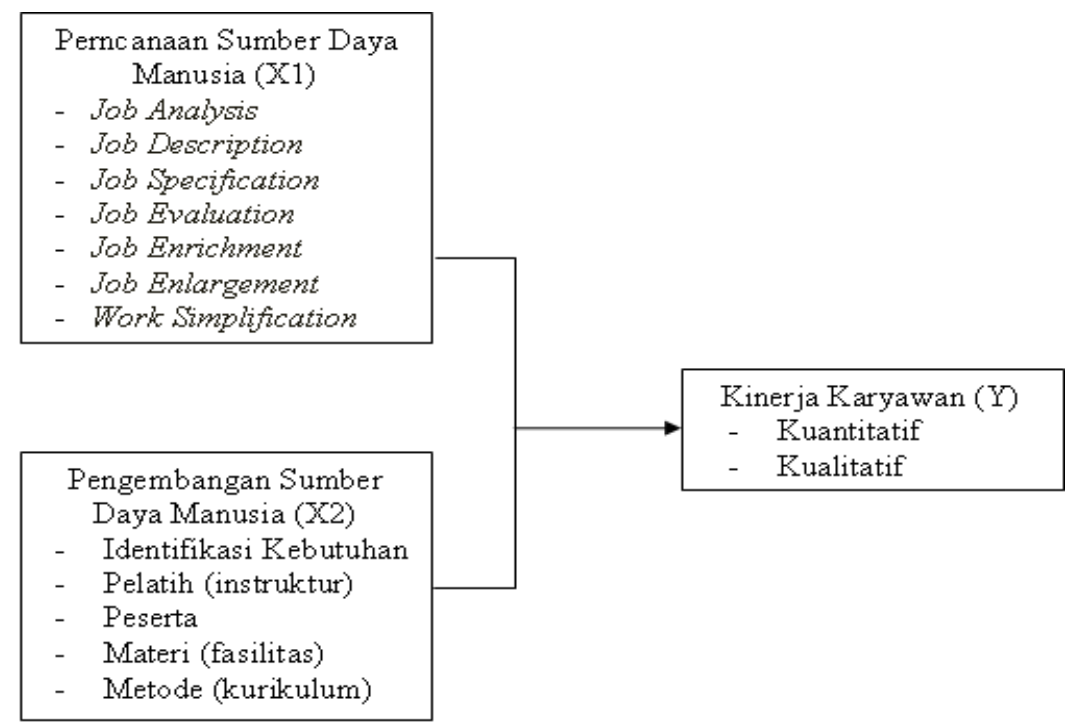

Gambar 1. Kerangka Penelitian

Hipotesis dalam penelitian ini adalah sebagai berikut $\mathrm{H} 1$, diduga perencanaan sumber daya manusia berpengaruh signifikan terhadap kinerja karyawan. H2, diduga pengembangan sumber daya manusia berpengaruh signifikan terhadap kinerja karyawan.

\section{METODE PENELITIAN}

Penelitian dilakukan di PT Permata Bahari Malindonesia yang beralamat di Jl. Madrasah Desa Sampangan Kecamatan Muncar Kabupaten Banyuwangi. Penelitian ini adalah penelitian deskriptif dengan menggunakan survey, dimana peneliti melakukan penyebaran kuesioner dalam mengumpulkan data yang diperlukan. Dengan melakukan penyebaran kuesioner diharapkan memperoleh tanggapan responden terhadap kuesioner atau sejumlah pertanyaan kepada seluruh objek penelitian. Data primer yang diperoleh langsung dari kuesioner yang diberikan kepada karyawan bagian pemotongan ikan PT Permata Bahari Malindonesia yang berkaitan dengan persepsi karyawan tentang perencanaan dan pengembangan sumber daya manusia serta tingkat kinerja karyawan.

Selain itu data yang berasal dari karyawan bagian pemotongan 
ikan yang digunakan dalam penelitian ini yaitu karakteristik responden yang ditinjau dari jenis kelamin, pendidikan, masa kerja, dan usia karyawan. Data sekunder dalam penelitian ini berupa gambaran umum PT Permata Bahari Malindonesia, sejarah singkat perusahaan, serta data karyawan berkaitan dengan jumlah karyawan. Populasi yang akan diteliti adalah semua karyawan produksi bagian gunting atau pemotongan yang berjumlah 189 orang.

Sampel merupakan bagian dari populasi yang ingin di teliti oleh peneliti. Dalam teknik pengambilan sampel ini peneliti menggunakan teknik random sampling yaitu teknik penentuan sampel dimana semua individu dalam populasi baik secara sendirisendiri atau bersama-sama diberi kesempatan yang sama untuk dipilih sebagai anggota sampel (Sugiyono, 2002:78). Sampel yang digunakan peneliti adalah karyawan bagian pemotongan ikan PT Permata Bahari Malindonesia dengan cara memberikan kesempatan kepada smua karyawan untuk menjadi anggota sampel.

Menurut Arikunto (2006:112), apabila subjeknya kurang dari 100 lebih baik diambil semua sehingga sampel merupakan keseluruhan dari populasi. Tetapi jika subjeknya besar atau lebih dari 100 maka dapat diambil $10 \%-15 \%$ atau $15 \%-25 \%$ atau lebih. Pendapat tersebut sesuai dengan Roscoe dalam Sugiyono (2011:90), untuk sampel yang layak dalam penelitian adalah antara 30 sampai 500. Berdasarkan pendapat tersebut maka peneliti menentukan pengambilan sampel sebesar 20\% dari jumlah populasi sebanyak 38 orang.

Tabel 2. Hasil Pengujian Validitas Perencanaan SDM (X1)

\begin{tabular}{|c|c|c|c|c|}
\hline $\begin{array}{c}\text { Variabel } \\
\text { Perencanaan SDM }\end{array}$ & Item & Koefisien Korelasi & $\mathrm{R}_{\text {tabel }}$ & Keterangan \\
\hline \multirow[t]{4}{*}{ Job Analysis } & $\mathrm{X} 1.1$ & 0,879 & 0,2638 & Valid \\
\hline & $\mathrm{X} 1.2$ & 0,893 & 0,2638 & Valid \\
\hline & $\mathrm{X} 1.3$ & 0,879 & 0,2638 & Valid \\
\hline & $\mathrm{X} 1.4$ & 0,932 & 0,2638 & Valid \\
\hline \multirow[t]{4}{*}{ Job Description } & $\mathrm{X} 1.5$ & 0,778 & 0,2638 & Valid \\
\hline & X1.6 & 0,844 & 0,2638 & Valid \\
\hline & $\mathrm{X} 1.7$ & 0,812 & 0,2638 & Valid \\
\hline & $\mathrm{X} 1.8$ & 0,893 & 0,2638 & Valid \\
\hline \multirow[t]{4}{*}{ Job Spesification } & $\mathrm{X} 1.9$ & 0,789 & 0,2638 & Valid \\
\hline & $\mathrm{X} 1.10$ & 0,915 & 0,2638 & Valid \\
\hline & $\mathrm{X} 1.11$ & 0,975 & 0,2638 & Valid \\
\hline & $\mathrm{X} 1.12$ & 0,917 & 0,2638 & Valid \\
\hline \multirow[t]{4}{*}{ Job Evaluation } & $\mathrm{X} 1.13$ & 0,915 & 0,2638 & Valid \\
\hline & $\mathrm{X} 1.14$ & 0,740 & 0,2638 & Valid \\
\hline & $\mathrm{X} 1.15$ & 0,670 & 0,2638 & Valid \\
\hline & $\mathrm{X} 1.16$ & 0,817 & 0,2638 & Valid \\
\hline \multirow[t]{4}{*}{ Job Enrichment } & $\mathrm{X} 1.17$ & 0,846 & 0,2638 & Valid \\
\hline & $\mathrm{X} 1.18$ & 0,846 & 0,2638 & Valid \\
\hline & $\mathrm{X} 1.19$ & 0,846 & 0,2638 & Valid \\
\hline & $\mathrm{X} 1.20$ & 0,846 & 0,2638 & Valid \\
\hline \multirow[t]{4}{*}{ Job Enlargement } & $\mathrm{X} 1.21$ & 0,859 & 0,2638 & Valid \\
\hline & $\mathrm{X} 1.22$ & 0,775 & 0,2638 & Valid \\
\hline & $\mathrm{X} 1.23$ & 0,809 & 0,2638 & Valid \\
\hline & $\mathrm{X} 1.24$ & 0,858 & 0,2638 & Valid \\
\hline \multirow[t]{4}{*}{ Work Satisfaction } & $\mathrm{X} 1.25$ & 0,821 & 0,2638 & Valid \\
\hline & $\mathrm{X} 1.26$ & 0,688 & 0,2638 & Valid \\
\hline & $\mathrm{X} 1.27$ & 0,975 & 0,2638 & Valid \\
\hline & $\mathrm{X} 1.28$ & 0,868 & 0,2638 & Valid \\
\hline
\end{tabular}




\section{HASIL PENELITIAN DAN PEMBAHASAN}

Dari Tabel 2 dapat dilihat bahwa semua item variabel diatas menyatakan valid. Nilai pearson correlation ( $\mathrm{r}$ ) untuk variabel independen Perencanaan SDM (X1) berkisar antara 0.879 sampai dengan 0.868 . Nilai $r$ hitung dari masingmasing item lebih besar dari $r$ tabel (0.2638). Oleh karena itu, maka dapat ditarik suatu kesimpulan bahwa semua item dari variabel independen perencanaan sumber daya manusia (X1) memiliki tingkat kevalidan yang baik dan dapat digunakan untuk penelitian selanjutnya.

Semua item variabel diatas dinyatakan valid. Nilai pearson correlation (r) untuk variabel independen Kinerja Karyawan (Y) berkisar antara $0 \mathrm{~m} 835$ sampai dengan 0,846. Nilai $r$ hitung dari masing-masing item lebih besar dari $\mathrm{r}$ tabel (0.2638) oleh karena itu, maka dapat ditarik suatu kesimpulan bahwa semua item dari variabel independen kinerja (Y) memiliki tingkat kevalidan yang baik dan dapat digunakan untuk penelitian selanjutnya.

Nilai koefisien reliabilitas untuk semua variabel lebih besar dari 0,6 maka jawaban responden atas pertanyaan mengenai perencanaan sumber daya manusia, dan kinerja karyawan dapat diandalkan (reliabel), artinya jawaban karyawan konsisten sehingga apabila dilakukan penelitian sejenis pada waktu yang berbeda maka responden akan memberikan jawaban yang sama.

Nilai koefisien reliabilitas untuk semua variabel lebih besar dari 0,6 maka jawaban responden mengenai perencanaan sumber daya manusia, pengembangan sumber daya manusia, dan kinerja karyawan dapat diandalkan (reliabel), dalam arti jawaban karyawan tidak mengarah kepada jawaban-jawaban tertentu sehingga apabila dilakukan penelitian sejenis pada waktu yang berbeda maka responden akan memberikan jawaban yang sama dengan penelitian saat ini. 
Tabel 3. Hasil Analisis Data Rentang Skala Variabel Perencanaan (X1)

\begin{tabular}{|c|c|c|c|c|c|c|c|c|}
\hline \multirow[t]{2}{*}{ Item } & \multicolumn{5}{|c|}{ Jawaban Responden } & \multirow{2}{*}{$\begin{array}{c}\text { Jumlah } \\
\text { Responden }\end{array}$} & \multirow[t]{2}{*}{ Jumlah Skor } & \multirow[t]{2}{*}{ Kriteria Penilaian } \\
\hline & 5 & 4 & 3 & 2 & 1 & & & \\
\hline $\mathrm{X} 1.1$ & 14 & 22 & 2 & 0 & 0 & 38 & 164 & Sangat Baik \\
\hline $\mathrm{X} 1.2$ & 15 & 23 & 0 & 0 & 0 & 38 & 167 & Sangat Baik \\
\hline $\mathrm{X} 1.3$ & 14 & 22 & 2 & 0 & 0 & 38 & 164 & Sangat Baik \\
\hline $\mathrm{X} 1.4$ & 14 & 24 & 0 & 0 & 0 & 38 & 166 & Baik \\
\hline $\mathrm{X} 1.5$ & 12 & 24 & 0 & 0 & 0 & 38 & 156 & Sangat Baik \\
\hline X1.6 & 14 & 20 & 4 & 0 & 0 & 38 & 162 & Sangat Baik \\
\hline $\mathrm{X} 1.7$ & 16 & 22 & 0 & 0 & 0 & 38 & 168 & Sangat Baik \\
\hline $\mathrm{X} 1.8$ & 15 & 23 & 0 & 0 & 0 & 38 & 167 & Sangat Baik \\
\hline X1.9 & 13 & 20 & 5 & 0 & 0 & 38 & 160 & Sangat Baik \\
\hline $\mathrm{X} 1.10$ & 14 & 24 & 0 & 0 & 0 & 38 & 166 & Sangat Baik \\
\hline $\mathrm{X} 1.11$ & 13 & 25 & 0 & 0 & 0 & 38 & 165 & Sangat Baik \\
\hline $\mathrm{X} 1.12$ & 13 & 24 & 1 & 0 & 0 & 38 & 164 & Sangat Baik \\
\hline $\mathrm{X} 1.13$ & 14 & 24 & 0 & 0 & 0 & 38 & 166 & Sangat Baik \\
\hline X1.14 & 11 & 19 & 7 & 1 & 0 & 38 & 154 & Baik \\
\hline $\mathrm{X} 1.15$ & 16 & 20 & 2 & 0 & 0 & 38 & 166 & Sangat Baik \\
\hline $\mathrm{X} 1.16$ & 18 & 20 & 0 & 0 & 0 & 38 & 170 & Sangat Baik \\
\hline $\mathrm{X} 1.17$ & 18 & 20 & 0 & 0 & 0 & 38 & 170 & Sangat Baik \\
\hline X1.18 & 18 & 20 & 0 & 0 & 0 & 38 & 170 & Sangat Baik \\
\hline X1.19 & 18 & 20 & 0 & 0 & 0 & 38 & 170 & Sangat Baik \\
\hline $\mathrm{X} 1.20$ & 18 & 20 & 0 & 0 & 0 & 38 & 170 & Sangat Baik \\
\hline $\mathrm{X} 1.21$ & 17 & 21 & 0 & 0 & 0 & 38 & 169 & Sangat Baik \\
\hline $\mathrm{X} 1.22$ & 14 & 19 & 4 & 1 & 0 & 38 & 160 & Sangat Baik \\
\hline $\mathrm{X} 1.23$ & 18 & 20 & 0 & 0 & 0 & 38 & 170 & Sangat Baik \\
\hline $\mathrm{X} 1.24$ & 16 & 22 & 0 & 0 & 0 & 38 & 168 & Sangat Baik \\
\hline $\mathrm{X} 1.25$ & 15 & 18 & 5 & 0 & 0 & 38 & 162 & Sangat Baik \\
\hline $\mathrm{X} 1.26$ & 22 & 16 & 0 & 0 & 0 & 38 & 174 & Sangat Baik \\
\hline $\mathrm{X} 1.27$ & 13 & 25 & 0 & 0 & 0 & 38 & 165 & Sangat Baik \\
\hline $\mathrm{X} 1.28$ & 14 & 21 & 3 & 0 & 0 & 38 & 163 & Sangat Baik \\
\hline \multicolumn{7}{|c|}{ Total Skor } & 4614 & Sangat Baik \\
\hline \multicolumn{7}{|c|}{ Skor Rata-rata } & 165 & Sangat Baik \\
\hline
\end{tabular}

Hasil analisis menunjukkan rata-rata variabel perencanaan (job analisis, job description, job spesification, job evaluation, job enrichment, job enlargement dan work simplification) sangat baik (skor 165). Hasil ini menunjukkan bahwa perusahaan memiliki perencanaan sumber daya manusia yang

baik.

Tabel 4. Hasil Analisis Data Rentang Skala Variabel Pengembangan SDM (X2)

\begin{tabular}{|c|c|c|c|c|c|c|c|c|}
\hline \multirow[t]{2}{*}{ Item } & \multicolumn{5}{|c|}{ Jawaban Responden } & Jumlah & \multirow[t]{2}{*}{ Jumlah Skor } & \multirow{2}{*}{$\begin{array}{c}\text { Kriteria } \\
\text { Penilaian }\end{array}$} \\
\hline & 5 & 4 & 3 & 2 & 1 & Responden & & \\
\hline $\mathrm{X} 2.1$ & 15 & 23 & 0 & 0 & 0 & 38 & 167 & Sangat Baik \\
\hline $\mathrm{X} 2.2$ & 16 & 22 & 0 & 0 & 0 & 38 & 168 & Sangat Baik \\
\hline $\mathrm{X} 2.3$ & 13 & 25 & 0 & 0 & 0 & 38 & 165 & Sangat Baik \\
\hline X2.4 & 15 & 23 & 0 & 0 & 0 & 38 & 167 & Sangat Baik \\
\hline $\mathrm{X} 2.5$ & 13 & 25 & 0 & 0 & 0 & 38 & 155 & Sangat Baik \\
\hline $\mathrm{X} 2.6$ & 13 & 25 & 0 & 0 & 0 & 38 & 165 & Sangat Baik \\
\hline $\mathrm{X} 2.7$ & 14 & 21 & 2 & 1 & 0 & 38 & 162 & Sangat Baik \\
\hline $\mathrm{X} 2.8$ & 15 & 22 & 1 & 0 & 0 & 38 & 166 & Sangat Baik \\
\hline $\mathrm{X} 2.9$ & 14 & 24 & 0 & 0 & 0 & 38 & 166 & Sangat Baik \\
\hline $\mathrm{X} 2.10$ & 13 & 25 & 0 & 0 & 0 & 38 & 165 & Sangat Baik \\
\hline $\mathrm{X} 2.11$ & 13 & 24 & 0 & 0 & 0 & 38 & 164 & Sangat Baik \\
\hline $\mathrm{X} 2.12$ & 14 & 24 & 0 & 0 & 0 & 38 & 166 & Sangat Baik \\
\hline X2.13 & 14 & 24 & 0 & 0 & 0 & 38 & 166 & Sangat Baik \\
\hline X2.14 & 14 & 24 & 0 & 0 & 0 & 38 & 166 & Sangat Baik \\
\hline \multirow[t]{3}{*}{$\mathrm{X} 2.15$} & 17 & 21 & 0 & 0 & 0 & 38 & 169 & Sangat Baik \\
\hline & \multicolumn{5}{|c|}{ Total } & & 2487 & \\
\hline & \multicolumn{5}{|c|}{ Skor rata-rata } & & 165 & Sangat Baik \\
\hline
\end{tabular}


Hasil analisis menunjukkan rata-rata variabel pengembangan sumber daya manusia (kebutuhan pendidikan, pelatihan peserta pendidikan, materi, dan metode) dalam kategori sangat baik (skor 165). Hasil ini menunjukkan bahwa pengembangan sumber daya manusia telah dilakukan dengan programprogram berupa pendidikan, pelatihan dan diharapkan mampu menjadikan kualitas karyawan lebih tinggi dan mampu melaksanakan tugas dengan lebih baik lagi.

Tabel 5. Hasil Analisis Data Rentang Skala Variabel Kinerja Karyawan (Y)

\begin{tabular}{ccccccccc}
\hline Item & \multicolumn{9}{c}{ Jawaban Responden } & Jumlah & Jumlah Skor & Kriteria Penilaian \\
& 5 & 4 & 3 & 2 & 1 & Responden & \\
\hline Y1 & 14 & 22 & 2 & 0 & 0 & 38 & 164 & Sangat Tinggi \\
Y2 & 18 & 20 & 0 & 0 & 0 & 38 & 170 & Sangat Tinggi \\
Y3 & 15 & 23 & 0 & 0 & 0 & 38 & 167 & Sangat Tinggi \\
Y4 & 6 & 30 & 2 & 0 & 0 & 38 & 156 & Tinggi \\
Y5 & 7 & 27 & 4 & 0 & 0 & 38 & 155 & Tinggi \\
Y6 & 15 & 23 & 0 & 0 & 0 & 38 & 167 & Sangat Tinggi \\
Y7 & 6 & 30 & 2 & 0 & 0 & 38 & 156 & Tinggi \\
Y8 & 18 & 20 & 0 & 0 & 0 & 38 & 170 & Sangat Tinggi \\
& \multicolumn{9}{c}{ Total } \\
\hline
\end{tabular}

Hasil analisis dapat diketahui bahwa rata-rata variabel kinerja karyawan dalam kategori sangat tinggi dengan skor rata-rata sebesar 163. Hasil tersebut menunjukkan bahwa karyawan telah melaksanakan tugas sesuai dengan ketentuan atau standar dari perusahaan dan mampu meningkatkan kinerjanya dengan lebih baik.

Tabel 6. Hasil Rekapitulasi Uji Regresi Linier Berganda

\begin{tabular}{llll}
\hline Variabel & Koefisien Regresi & $\mathrm{T}_{\text {hitung }}$ & Sig-t \\
\hline Perencanaan SDM (X1) & 0.741 & 5.658 & 0.000 \\
Pengembangan SDM (X2) & 0.500 & 4.308 & 0.000 \\
Variabel & & Keterangan & \\
Tarif Sig $\alpha$ & & 0.05 & \\
Konstanta & & 13.120 & \\
$\mathrm{R}$ & & 0.847 & \\
$\mathrm{R}^{2}$ & 0.718 & \\
\hline
\end{tabular}

Berdasarkan perhitungan regresi Tabel 6 diatas diperoleh persamaan regresi linier berganda sebagai berikut : $\mathrm{Y}=13.120+$ $0.741_{\mathrm{X} 1}+0.500_{\mathrm{X} 2}+$ e. Hal ini menunjukkan besarnya nilai variabel dependen kinerja karyawan jika variabel independen perencanaan sumber daya manusia dan pengembangan sumber daya manusia dianggap nol, artinya jika tanpa dipengaruhi oleh variabel independen.
Hal ini juga menunjukkan besarnya nilai variabel independen perencanaan sumber daya manusia yang menunjukkan pengaruh positif yang dapat diartikan jika perencanaan sumber daya manusia yang dilakukan dengan baik maka tujuan-tujuan perusahaan yang telah direncanakan yang berkaitan dengan sumber daya manusia akan tercapai sesuai dengan apa yang telah direncanakan sebelumnya. Hal ini menunjukkan bahwa dengan adanya 
perencanaan sumber daya manusia akan memudahkan perusahaan untuk melakukan koordinasi, integrasi, serta sinkronisasi terhadap karyawan sehingga mampu meningkatkan kinerja karyawan.

Selain itu, menunjukkan besarnya nilai variabel independen pengembangan sumber daya manusia yang menunjukkan pengaruh positif yang artinya jika pengembangan diberikan kepada karyawan maka karyawan mampu melaksanakan tugas dan tanggung jawab secara maksimal. Hal tersebut ditunjukkan dengan adanya karyawan semakin berkembang dan memahami tugas yang harus dilakukan dengan baik.

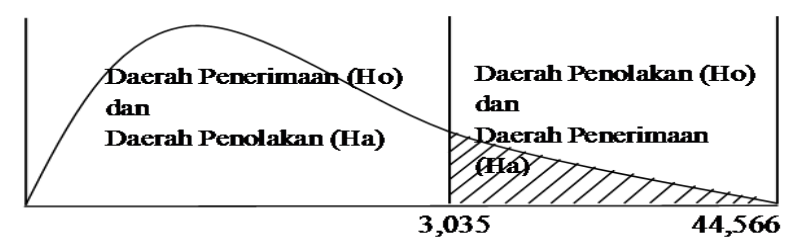

Gambar 2. Kurva Penerimaan Ha dan Penolakan Ho Secara Simultan

Berdasarkan perhitungan uji $\mathrm{F}$ pada gambar kurva 4.2 diatas maka diperoleh nilai $F_{\text {hitung }}$ sebesar 44,566 dan nilai $\mathrm{F}_{\text {tabel }}$ sebesar 3,035 dengan taraf $5 \%$. Maka hipotesis $\mathrm{H}_{0}$ ditolak dan $\mathrm{H}_{\mathrm{a}}$ diterima.
Artinya semua variabel independen (perencanaan dan pengembangan sumber daya manusia) secara bersama-sama berpengaruh terhadap kinerja karyawan.

Tabel 7. Hasil Uji T Masing-masing Variabel

\begin{tabular}{lccc}
\hline Variabel & $\mathrm{T}_{\text {hitung }}$ & Signifikansi & Tingkat Kepercayaan \\
\hline Perencanaan SDM (X1) & 5.658 & 0.000 & $95 \%$ \\
Pengembangan SDM (X2) & 4.308 & 0.000 & $95 \%$ \\
\hline
\end{tabular}

Berdasarkan Tabel diatas dapat diketahui besarnya pengaruh masingmasing variabel sebagai berikut ini: Variabel perencanaan SDM (X1) memiliki nilai $t_{\text {hitung }}$ sebesar 5.658dengan signifikansi sebesar 0.000 sedangkan nilai $t_{\text {tabel }}$ sebesar 2.758. Pengujian ini menunjukkan bahwa nilai $5.658 \mathrm{t}_{\text {hitung }}>$ nilai $\mathrm{t}_{\text {tabel }} 2.758$. Hal ini menunjukkan bahwa variabel perencanaanSDM berpengaruh secara signifikan terhadap variabel kinerja karyawan Variabel pengembangan SDM (x2) memiliki nilai $t_{\text {hitung }}$ sebesar 4.308dengan signifikansi sebesar
0.000 sedangkan nilai $t_{\text {tabel }}$ sebesar 2.758, pengujian ini menunjukkan bahwa nilai $4.308 t_{\text {hitung }}>$ nilai $t_{\text {tabel }}$ 2.758. Maka dapat disimpulkan bahwa variabel pengembangan SDM berpengaruh secara signifikan terhadap variabel kinerja karyawan.

\section{SIMPULAN}

Perencanaan sumber daya manusia yang meliputi (job analysis, job description, job specification, job evalution, job enrichment, job enlargement, dan work simplification) tergolong pada kategori sangat baik, yang 
membuktikan bahwa perusahaan telah melakukan perencanaan terhadap sumber daya manusianya sehingga sumber daya manusia yang dimiliki perusahaan telah sesuai dengan kebutuhan perusahaan serta efektif dan efisien dalam membantu terwujudnya tujuan perusahaan. Sedangkan pengembangan sumber daya manusia yang meliputi (kebutuhan pendidikan, pelatih, peserta pendidikan, materi, dan metode) termasuk pada kategori sangat baik.

Hal ini menunjukkan bahwa perusahaan telah melakukan pengembangan sumber daya manusia dengan malaksanakan programprogram pendidikan dan pelatihan guna untuk meningkatkan kualitas karyawan yang agar mampu melaksakan tugas dan tanggung jawabnya masing-masing dengan baik.

Begitupula kinerja karyawan PT Permata Bahari Malindonesia termasuk pada kategori sangat tinggi yang menunjukkan bahwa karyawan telah melaksakan suatu tujuan dan program-program dari perusahaan yang dituangkan dalam perencanaan dan pengembangan sumber daya manusia. 2) Terdapat pengaruh yang signifikan antara perencanaan sumber daya manusia terhadap kinerja karyawan PT Permata Bahari Malindonesia. 3) Terdapat pengaruh signifikan antara pengembangan SDM terhadap kinerja karyawan.

\section{DAFTAR PUSTAKA}

Arikunto, S, 2006. Prosedur Penelitian Suatu Pendekatan Praktik, Edisi Revisi Keempat, Rineka Cipta, Jakarta.
Bakar, A, 2011, Perencanaan Sumber Daya Manusia yang Efektif, Widyaiswara Madya BDK. Palembang.

Bangun, Wilson, 2012, Manajemen Sumber Daya Manusia, Erlangga, Jakarta.

Hasibuan, Malayu S.P., 2003, Manajemen Sumber Daya Manusia, Bumi Aksara, Jakarta.

Mangkunegara, A.A. Anwar Prabu, 2006, Perencanaan dan Pengembangan Sumber Daya Manusia, Rafika Aditama, Bandung.

McLeod, Raymond Jr. dan George Schell, 2004, Sistem Informasi Manajemen, Edisi kedelapan, PT Indeks, Jakarta.

Moehariono, 2010, Pengukuran Kinerja Berbasis Kompetensi, Ghalia Indonesia, Bogor.

Nawawi, Hadari, 2011, Manajemen Sumber Daya Manusia, Gadjah Mada University Press, Yogyakarta

Riduan dan Kuncoro, 2008, Cara Menggunakan dan Memaknai Analisis Jalur, Alfabeta. Bandung.

Rivai, Veithzal, 2004, Manajemen Sumber Daya Manusia, Untuk Perusahaan, cetakan pertama, Raja Grafindo, Jakarta.

Sanusi, Anwar, 2013, Metodelogi Penelitian Bisnis, Salemba Empat, Jakarta.

Simamora, Henry, 1997, Manajemen Sumber Daya Manusia, Edisi kedua, STIE YKPN, Yogyakarta.

Singodimedjo, Markum, 2000, Manajemen Sumber Daya 
Manusia, SMMAS, Surabaya. Sudjana, 2006, Metode Statistika, Edisi Keenam, Tasito, Bandung.

Sugiyono, 2002, Metode Penelitian Bisnis, Alphabeta, Bandung. Sutrisno, Edy, 2009, Manajmen Sumber Daya Manusia, Edisi pertama, Kencana, Jakarta.

Umar, Husein, 2003, Metode Riset Bisnis, Gramedia Pustaka Utama, Jakarta.

Wibowo, 2011. Manajemen Kinerja, Edisi Ketiga, Rajawali Pers, Jakarta 